\section{Pecan Leaf Analysis Is Not Improved by Washing}

\author{
Ray E. Worley ${ }^{1}$ \\ Coastal Plain Experiment Station, Department of Horticulture, Universit. \\ Georgia, Tifton, GA 31793
}

Additional index words. Carya illinoinensis

The reporting of micronutrient data from pecan [Carya illinoinensis (Wangenh.) K. Koch] leaves in ASHS publications was disallowed because the leaves were not washed. However, few growers in the southeastern United States use nutrient sprays, and frequent rains wash leaves naturally. Jones and Wallace (1992) reviewed the research on washing leaf samples and concluded that washing normally is not necessary if the tissue is selected carefully and $\mathrm{Fe}, \mathrm{Al}$, and $\mathrm{Si}$ are not elements of primary interest. In a Texas study (Smith and Storey, 1976), pecan leaves not sprayed with or dipped in a nutrient solution contained equal or lower concentrations of elements than those dipped in a nutrient solution and then washed, a result indicating that nonsprayed leaves were free of contaminating elements that may be removed by washing. Leaves sprayed with $\mathrm{Zn}$ or dipped in micronutrient solutions were best cleaned with a detergent plus $\mathrm{HCl}$ wash (Smith and Storey, 1976). Similarly washed apple, peach, and cherry leaves that had not been dipped in nutrient solutions contained $\mathrm{N}, \mathrm{Mg}, \mathrm{Zn}, \mathrm{Fe}, \mathrm{Mn}, \mathrm{B}$, and $\mathrm{K}$ concentrations similar to those in nonwashed and nondipped samples. Samples dipped in nutrient solutions, however, needed to be washed (Ashby, 1969).These events prompted the present study to determine the effect of washing on the elemental concentration of pecan leaves that received no nutrient sprays and to evaluate the necessity of washing visually clean pecan leaves before analysis.

Received for publication 30 Oct. 1992. Accepted for publication 12 Apr. 1993. The cost of publishing this paper was defrayed in part by the payment of page charges. Under postal regulations, this paper therefore must be hereby marked advertisement solely to indicate this fact.

'Professor. nutrient sprays.

${ }^{2}$ From analysis of variance $F$ test.
Thirty-two pecan leaf samples were collected from a composite of $\approx 15$ - to 18 -m-tall, 67-year-old 'Stuart' and 'Schley' trees from experimental plots near Plains, Ga. Samples were collected from the area of maximum limb spread ( $\approx 9 \mathrm{~m}$ from the ground); therefore, they were not affected by ground spattering from rain. No nutrient sprays were applied. Insects and diseases were controlled by ground sprays with an air-blast sprayer. Tin in the fungicide was the only metal sprayed on the foliage.

One-half of each sample was swirled for $<1 \mathrm{~min}$ in a detergent solution (Alconox, New York), rinsed in tap water, dipped in $1 \% \mathrm{HCl}$, rinsed three times in distilled water, and blotted on paper towels according to the procedure of Smith and Storey (1976). The other half was not washed. Samples were oven-dried at $\approx 90 \mathrm{C}$ and then ground to pass through a $850-\mu \mathrm{m}-$ aperture (20-mesh) screen. Cations were analyzed by atomic absorption spectroscopy and P was analyzed by calorimetry (Worley, 1990). Means were compared using SAS PROC ANOVA (SAS Institute, 1989).

When data were analyzed as 32 replications of washed vs. nonwashed treatments, only $\mathrm{Zn}$ and $\mathrm{Mn}$ concentrations were significantly different in washed vs. non washed leaves (Table 1). Leaf concentrations of any element tested did not decrease significantly after leaves were washed. The unexplained increase in $\mathrm{Zn}$ and $\mathrm{Mn}$ concentrations in washed samples suggests that leaves may have been contaminated during washing. There was excellent agreement for washed and nonwashed samples, and differences were not significant except for $\mathrm{Mn}$, which was very high in washed and nonwashed leaves.

Our analysis indicated that there was no benefit to washing visually clean leaves when they were not sprayed with the elements analyzed. Leaves from trees receiving foliar nutrient sprays and leaves visually contaminated with dust or elements should be washed before analysis (Ashby, 1969; Smith and Storey, 1976). There was no apparent source of elemental contamination in this orchard or in most orchards in the area. This study confirms the recommended practice of not washing leaves unless they are visually contaminated or unless a nutrient spray has been applied (Plank, 1989).

\section{Literature Cited}

Ashby, D.L. 1969. Washing techniques for the removal of nutrient element deposits from the surface of apple, cherry, and peach leaves. J. Amer. Soc. Hort. Sci. 94:266-268.

Jones, J.B, Jr., and A. Wallace. 1992. Sample preparation and determination of $\mathrm{Fe}$ in plant tissue samples. J. Plant Nutr. 15(10):2085-2108.

Plank, CO. 1989. Plant analysis handbook for Georgia. Ga. Coop. Ext. Serv.

SAS Institute. 1989. SAS/STAT user's guide. version 6.4th ed. vol. 1. SAS Institute, Cary, N.C.

Smith, M.W. and J.B. Storey. 1976. The influence of washing procedures on surface removal and leaching of certain elements from pecan, Carya illinoensis, leaflets. HortScience 11:50-52.

Worley, R.E. 1990. Long-term performance of pecan trees when nitrogen application is based on prescribed threshold concentrations in leaf tissue. J. Amer. Soc. Hort. Sci. 115:745-749.

Table 1. Concentrations of elements in nonwashed and washed pecan leaves from trees that did not receive

\begin{tabular}{|c|c|c|c|c|c|c|c|c|}
\hline \multirow[b]{3}{*}{ Treatment } & \multicolumn{8}{|c|}{ Elemental concn } \\
\hline & $\mathbf{P}$ & $\mathrm{K}$ & $\mathrm{Ca}$ & $\mathrm{Mg}$ & $\mathrm{Zn}$ & Mn & $\mathrm{Fe}$ & $\mathrm{Cu}$ \\
\hline & \multicolumn{4}{|c|}{$\left(m g \cdot g^{-1}\right)$} & \multicolumn{4}{|c|}{$\left(\mu \mathrm{g} \cdot \mathrm{g}^{-1}\right)$} \\
\hline Nonwashed & 1.5 & 8.6 & 13.6 & 5.0 & 69 & 754 & 47 & 7.2 \\
\hline Washed & 1.4 & 8.8 & 14.0 & 5.0 & 75 & 838 & 49 & 7.6 \\
\hline$P>\mathrm{F}^{\mathrm{z}}$ & 0.24 & 0.39 & 0.27 & 1.0 & 0.05 & 0.01 & 0.10 & 0.21 \\
\hline
\end{tabular}

